\title{
Money Demand Dynamics: Some New Evidence
}

\author{
Daniel L. Thornton
}

SONSIDERABLF, empirical work and a significant, but considerably smaller, volume of theoretical effort has been devoted to the question of the short-run, dynamic adjustment of the demand for money. Much of the impetus for the empirical work came from the classic study by Chow (1966), who employed the partial adjustment model to characterize the adjustment of actual to desired real money balances.

Although there was early concern over the economics of Chow's specification and its relatively slow estimated speed of adjustment, this specification did not come under particularly close scrutiny until the unanticipated rise in velocity in the mid-1970s and the decine in velocity in the early $19805,{ }^{\prime}$ As a result, a number of altemative dynamic adjustment specificam tions have been developed. While these specifications differ in several fundamental respects, they fall into iwo general categories: those that assume the price level adjusts to exogenous changes in the money stock and those that assume the nominal money stock adjusts to exogenous changes in the price level. Consequently, three fundamentally different, short-run dynamic adjustment processes have been considered in the literature: the real adjustment specification of

Daniel $L$. Thornton is a senior economist at the Federal Reserve Bank of St. Louis. John G. Schufte provided research assistance. The author would like to thank Tom Fomby for useful comments on an earlier draft.

'See, for example, Goldteld (1976), Carr and Darby (1981), Coats (1982), Laidler (1980, 1982, 1983), Chant (1976), Judd and Scadding (1982a, 1982b), Hetzel (1984) and Motiey (1984).
Chow and the alternative nominal money and price adjustment specifications." These specifications have received considerable attention in the literature, with much of the empirical work devoted to determining which of these specifications is most consistent with the data, for example, Goldfeld (1976), Hafer and Hein (1980), Judd and Scadding (1982a), Coats (1983), Milbourne (1983), Hetzel (1984) and Motley (1984).

The purpose of this paper is threefold. First we review the literature on these specifications and point out that none of them can be thought of as representing adequately the short-run adjustment of actual to desired money when applied to aggregate data. Second, we demonstrate that none of these three specifications are directly comparable statistically. ${ }^{3}$ Consequently, the relative performance of these alternatives can be assessed only by their conformity with

\footnotetext{
"Nearly all of the specitications that have been suggested in the literature fall into one of these basic categories, at least to the extent that they have the price level, nominal money or real money as the dependent variables. Furthermore, many of the specific alternatives are concerned with how the demand for real money balances adjusts to changes in its arguments and, as such, are consistent with any of the three fundamental adiustment processes considered here.

It has been recognized, especially recently, that these alternatives are nonnested, i.e., none can be obtained by placing restrictions on any of the others. Consequently, most studies compare the forecasts of real money [e.g., Hafer and Hein $(1980)$ and Goidfeld (1976), or the residual sum of squares le.g., Judd and Scadding (1982a) and Coats] of alternative models. To date, only Motley (1984) has recognized that the nominal and price specifications are not comparable.
} 
theory and their stability. Finally, we investigate the performance of each specification using the same data and the same estimation period, II/1951-11/1984. The evidence suggests that none of these specifications have performed well over the entire period and none have been stable.

The issue of temporal stability is particularly important if one is to rely on short-run money demand in formulating short-run stabilization policy. If the shortrun demand for money is unstable, then attempts to stabilize output and prices in the short run through monetary control will be unsuccessful because differenf levels of output and prices will be consistent with a given stock of money at different points in time. This type of short-run instability, however, does not rule out the usefulness of monetary control for achieving economic stabilization over the longer run.

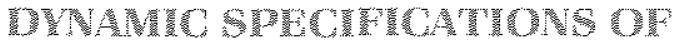 MONGW WWHAN}

All short-run money demand specifications are based on the long-run demand for money,

(1) $\mathrm{m}^{\mathrm{a}}=\mathrm{f}\left(\mathrm{X}_{r} \alpha_{r} \mathrm{u}_{1}\right)=\mathrm{f}\left(Z_{1}\right)$,

where $m$ denotes real money balances, $X$ is a set of endogenous and exogenous variables which usually includes some measure of real income or wealth and one or more interest rates, and $\alpha$ is a vector of unknown parameters. The error tem is denoted by $u$. All variables are in natural logs,

Chow based his short-run specification on the simple and convenient partial adjustment mechanism,

(2) $m_{1}-m_{t-1}=\lambda\left(m^{4}-m_{t-1}\right), \quad 0<\lambda \leq 1$.

He specified his adjustment process on the basis of individual economic behavior, arguing that individuals might adjust their actual stock of real money balances to the desired level in much the same way as they might adjust their actual stock of consumer durables to their desired level. This specification has been rationalized in a microeconomic framework in which the speed of adjustment $(\lambda)$ is detemined by the cost of being out of equilibrium relative to the cost of moving to equilibrium [for example, Motley (1967) and Feige (1967)].

"One could compare the ability of each model to forecast its dependent variable by, say, comparing percentage forecast errors (e.g., Hetzel). Such an exercise, while interesting, has little to say about the demand for money. Moreover, no objective comparison can be made, because there is no agreement about which variable is most important.
The peculiarity of this process was quickly pointed out by Walters (1967). He noted that, in the aggregate, market equilibrium requires that the demand for real money balances equals the supply of real money. If the nominal money stock is exogenous, equilibrium requires

(3) $\mathrm{M} / \mathrm{O}^{*}=\mathrm{m}^{\mathrm{d}}$

where $M$ and $P^{*}$ denote the nominal money stock and the long-run equilibrium price level, respectively. If $\mathrm{M}$ is fixed in the aggregate and the price level is adjusting to changes in $M$, equation 2 can be thought of as the price adjustment equation:

(4) $P_{1}-P_{t-1\}}=\lambda\left(P_{1}^{*}-P_{t-1}\right)^{5}$

The combination of equations 3 and 4 results in a specification that reflects Walters criticism of the Chow model and explicitly represents the so-called price adjustment specification considered by Gordon (1984), Laidler (1983), and Hetzel.

Goldfeld $(1973,1976)$, on the other hand, argued against Chow's specification on microeconomic grounds. He contended that it is defective because it implies that an individual adjusts real money balances fully and instantaneously to price level changes, but only partially to money demand changes." As an alternative, he offered the nominal adjustment specification,

(5) $M_{4}-M_{1-1}=\lambda\left(M_{1}^{i}-M_{t-1}\right)^{\prime} \quad 0<\lambda \leq 1$.

where $\mathrm{M}^{\mathrm{a}}$ denotes the desired level of nominal money. He argued that equation 5 makes more sense than

5Substituting equation 3 into equation 2 and holding $\mathrm{M}$ fixed $\operatorname{so} \mathrm{M}_{+}=$ $M_{t-3}=\mathrm{M}$, the resulting expression is equation 4 .

The reader should note that, while we have not changed notation, the interpretation of $\lambda$ in equation 4 is fundamentally different from that of equation 2. The same is true of the interpretation of $\lambda$ in equation 5 below.

This is most easity understood by noting that combining equation 2 with equation 1 implies not only that the long-run demand for nominal money is unil elastic with respect to price, but that the short-run nominal demand is as well.

This aspect of the real adjustment specification is not odd if one believes that money and bonds are close substitutes for each other, i.e. if a strict Keynesian liquidity preference holds. If money and fixed-dollar-denominated financial assets are held in some desired proportion given the interest rate, an unanticipated change in the price level will affect both money and financial assets proportionally so that an individuat's relative holdings of tinancial assets and money will be unatected. This will hold in either a pure asset model or in inventory theoretic transactions modes. Thus, it is not unreasonable to assume that an individual's demand for real money holdings adjusis instantaneously (or at least very quickly) to unanticipated price level changes if one believes that the only link between the real and financial sectors is the interest rate. 
equation 2 , a priori, because the adjustment of nominal money to a price level change is partial rather than instantaneous as equation 2 implies:

Gordon also argues for the nominal adjustment specification on microeconomic grounds." He maintains that there are no adjustment costs associated with price-induced changes in real money holdings and, consequently, the only costs involved in adjusting one's portfolio are those associated with adjusting nominal money balances."

laidler (1983) notes, however, that when equation 5 is applied to aggregate data, one commits the fallacy of composition if the aggregate nominal money stock is exogenous. Individuals are free to adjust their nominal balances, but society as a whole is not. Moreover, Hetzel observes that applying equation 5 to aggregate data is tantamount to assuming that the price level is exogenous to an endogenous nominal money stock. According to this interpretation, the monetary authority supplies the nominal money balances desired by the public with a lag. In this context, the nominal adjustment model is viewed as an equation representing the market equilibrium, where $\lambda$ is the adjustment parameter in the so-called Federal Reserve reaction function rather than the speed of adjustment of money demand. Given this interpretation, market equilibium requires

(6) $\mathrm{M}^{\mathrm{i}} / \mathrm{p}=\mathrm{m}^{\mathrm{t}}$

${ }^{7} \mathrm{By}$ the same reasoning, one could argue that the nominal adjustment specification implies that individuals never fully adjust to expecied inflation - see Carr and Darby. Both of these characterizations may be off the mark, however. A more reasonable model might allow both price level and nominal money shocks to affect the demand for money in the short run, but require them to average out to zero in the long run. This has been suggested recently by Gordon. For example, fet $\left(M_{1}^{*}-P_{*}^{*}\right)=f\left(Z_{1}\right)$ and combine this equation with equations 4 and 5 . The result is an equation that can be estimated given a further normalization rule: the residual sum of squares can be minimized in the direction of $M_{1}$ or $P_{\text {. }}$. Unfortunately, the results aze extremely sensitive to the normalization rule. In general, if one normalizes in the direction of $M_{1}$, the results are similar to (and often not statistically distinguishable from) those of the nominal specification. If one nofmalizes in the direction of $P_{\text {: }}$, the results are similar to the price adjustment specification. These resuts are available upon request

Ift is not clear exactly how Gordon means this. Certainly, individuals are free only to adjust their nominal money holdings since price mus be taken as given, however. Gordon cites the energy price shock as his only example. He argues that the supply shock reduces real income and, hence, the demand for teal money (presumably proportionally) so that no portfolio disequilibrium occurs.

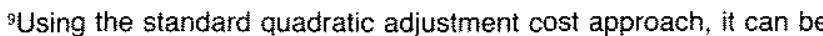
shown that the nominal specification results if adjustment costs are associated only with nominal money and if prices are given. See Hwang (1984). where $M^{*}$ denotes the aggregate level of nominal money balances desired by the public given the price level, $\mathrm{P}$.

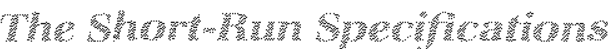

The above equations can be used to obtain the three shortrun money demand specifications. Equations 1 and 2 can be combined directly to obtain

(7) $\mathrm{m}_{4}=\lambda \mathrm{f}\left(\mathrm{Z}_{4}\right)+(1-\lambda)\left(\mathrm{m}_{1-1}\right)$

the real adjustment specification of Chow (1966).

Likewise, we can combine equations 3 with 4 , and 5 with 6 , to obtain what Laidler (1983) has termed quasireduced-form equations:

(8) $\left.\mathrm{m}_{\mathrm{g}}=\lambda \mathrm{f}\left(Z_{1}\right)+11-\lambda\right) \mathrm{M}_{\mathrm{k}-\mathrm{s}}-\mathrm{P}_{1}$

and

(9) $\mathrm{m}_{\mathrm{s}}=\lambda \mathrm{f}\left(\mathrm{Z}_{4}\right)+(1-\lambda)\left(\mathrm{M}_{\mathrm{t}}-\mathrm{P}_{1-1} \mathrm{I}\right.$

Because, ostensibly, all of these equations have real money on the left-hand side, it appears that these models can be compared using statistical techniques. This is incorrect

Note that the equations 8 and 9 could just as well be specified and estimated as

$\left(8^{\prime}\right) M_{4}=\lambda f\left(Z_{1}\right)+\left(1-\lambda M_{t-1}+\lambda P_{1}\right.$

and

$\left(9^{\prime}\right) P_{1}=-\lambda f\left(Z_{1}\right)+\left(1-\lambda P_{t-1}+\lambda M_{t}\right.$.

Comparing equations $7,8^{\prime}$ and $9^{\prime}$ reveals that they all have different dependent variables. Furthermore, no trivial transformation exists that will make these equa tions comparable; that is, regression equations cannot be manipulated algebraically to change the lett-handside variable to anything one pleases. Therefore, nothing can be said about which specification is preferred based on comparisons of these specifications, despite claims to the contrary. ISee the appendix for a mose detalled discussion.)

Alternatively, one can note that equations $8^{\prime}$ and $9^{\prime}$ make different assumptions about which variable is exogenous ite., prices and nominal money, respectively). Since, at best, only one of these assumptions is correct, consistent estimates of the errors can be obtained from only one of these equations. Hence, any comparison based on the residuals of these two specifications is inappropriate. Furthermore, theory alone cannot serve as a guide because, at the microeconomic level, the assumption of exogenous prices seems most relevant, while in the aggregate the exogeneity of nominal money is most plausible. 


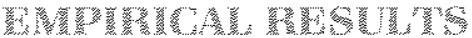

Because these alteratives are not statistically comparable, each should be evaluated for its consistency with the theory and its stability. ${ }^{30}$ Estimates of the real, nominal and price adjustment specifications are presented in this section. The estimates reported here cover the period II/1952-II/1984, which has been divided into three subperiods: IV/1951-IV/1961, 1/1962W/1973 and 1/1974-11/1984. This division is somewhat arbitrary; nevertheless, it has several aspects which make it desirable. First, the two earlier subperiods correspond closely to periods for which Goldfeld (1973) found the basic Chow equation to be stable Hence, it will be interesting to compare the estimates of the nominal and price adjustment specifications over these periods. Second. IV/1973 marks an observed break in the nominal and real adjustment specifications. ${ }^{13}$ Third, all three periods differ rather significantly with respect to the growth and variability of both money and prices." Finally, during the first two periods, the Federal Reserve was relying almost exclu" sively on an interest rate target, while, in the third period, more consideration was given to monetary aggregate targets. Hence, we might expect to see some deterioration in the performance of the nominal specification over the third period.

The real $(\mathbf{R})$, nominal ( $N$ ) and price (P) adjustment equations are estimated with ordinary least squares (OLS) to facilitate comparisons across time periods. Durbin's $h$-statistic is reported to illustrate how the error structure has varied among specifications and through time." Furthermore, all the equations were estimated with real money balances on the left-hand

10"Consistency with the theory" means that the coetficients should be statistically significant, correctly signed, and the adjustment coeff cient should obey its restriction. Thus, these equations are interpreted (as they have been in the literature) as money demand equations, it should be noted, however, that since equations 8 and $9^{\prime}$ are really quasi-reduced forms, neither is a particularty likely equation for explaining the nominal money stock or price fevel, respectively. I am indebted to Tom Fomby for this observation. He noticed that equation $9^{3}$ did not capture the monetarist notion of a long lag from money to prices.

"Hater and tein (1982) mark the break at $I V / 1973$, while Lin and $O$ h (1984) record it at $11 / 1974$

12The variances $(x 100)$ of $M$ and $P$, respectively, are 10.3449 , $0.4599),(3.2210,1.8107)$ and $(4.6474,4.7701)$ for the three per ods. The simple correlations between $M_{1}$ and $P_{4}$ over these periods are $0.9601,0.9947$ and 0.9911 .

13The equations also were estimated adjusting for first-order serial correlation using a maximum likelihood, grid-search procedure to estimate the coeficient of autocorrelation directly. In all instances, the qualitative conclusions were unatfected by the serial correlation correction. side, so that the signs of the coefficients are the same for all specifications." Also, since the nominal and price specifications represent over-identified, reduced-form equations, the reported F-statistic is for a test of the over-identifying restrictions; the results reported are for equations with the restriction imposed. ${ }^{1.5}$ Finally, the equations were estimated using real income $(y)$, the commercial paper rate (CPR) and the passbook savings rate (PBR) as independent variables. This specification of long run money demand represents a fairly standard version, following Goldfeld (1973). The equations are estimated with and without the PBR because numerous studies have found that similar variables have not been statistically significant over later periods, for example, Mafer and Hein (1980), Milbourne and Judd and Scadding (1982a).

\section{The}

Estimates of the three adjustment specifications for the three periods appear in table 1. Neither the real nor the nominal specifications performs well in the early period unless the PBR is included. Real income is insignificant in both equations and the over-identifying restriction is rejected at a very low significance level in the nominal specification when the savings rate is excluded. Furthermore, both the real and nominal specifications produce similar estimates of the coefficients over this period. The only striking difference is the apparent first-order serial correlation in the nominal specification, not present in the real equation.

Both the real and nominal specifications perform well in the last two periods in that all the parameters (save the constants) are significant and have the anticipated sign if the PBR is excluded. Including the PBR for the I/1962-IV/1973 period, however, tends to increase the estimated coefficient on real income markedly, while it reduces it in the /1974-H/1984 period. Indeed, real income is insignificant in the real specification in the last period if the PBR is included.

In contrast with the real and nominal specifications, real income is not significant in the price adjustment specification in the first period. Furthermore, it is sig-

\footnotetext{
4The adjusted $\mathrm{R}^{2}$ s are calculated for their respective dependent variable, however.

15The over-identifyng restriction for the nominal specification 8 ' is that the coefficients on $M_{1,1}$ and $P_{1}$ sum to one. The over-identifying restriction for this price specification is that the coefficients on $\mathrm{P}_{-1}$ and $\mathrm{M}_{1}$ sum to one.

16 The t-tests are one-talled if the coetficient has an anticipated sign, two-tailed otherwise.
} 
Table 1

Estimates of the Threo Basic Adjustment Equations

\begin{tabular}{|c|c|c|c|c|c|c|c|c|c|c|c|}
\hline Equation & Constant & $y$ & CPR & PER & $M_{1},-P_{11}$ & $\boldsymbol{M}_{2},-P_{1}$ & $\mathbf{M}-\mathbf{P}_{k-i}$ & $h$ & $\overline{\mathbf{R}^{*}}$ & $S E \times 10^{\circ}$ & $F$ \\
\hline \multicolumn{12}{|c|}{ W/1951-W/1961 } \\
\hline \multirow[t]{2}{*}{$R$} & $\begin{array}{r}854: \\
(372)\end{array}$ & $\begin{array}{r}.001 \\
0.06)\end{array}$ & $\begin{array}{l}.015^{*} \\
(4.62)\end{array}$ & & $\begin{array}{c}.842^{*} \\
(22.02)\end{array}$ & & & 1.52 & .9418 & 4828 & - \\
\hline & $\begin{array}{c}.674^{\circ} \\
(3.19)^{\prime}\end{array}$ & $\begin{array}{r}129^{*} \\
(3.20)\end{array}$ & $\begin{array}{r}.017^{*} \\
(5.83)\end{array}$ & $\begin{array}{l}-.034^{*} \\
(3.31)\end{array}$ & $\frac{.724^{\circ}}{(1466)}$ & & & 0.96 & .9537 & 4310 & - . \\
\hline \multirow[t]{2}{*}{$N$} & $\begin{array}{r}610^{\circ} \\
(2.79)\end{array}$ & $\begin{array}{r}.001 \\
\{0.05\}\end{array}$ & $\begin{array}{r}.012^{\circ} \\
(4.06)\end{array}$ & & & $\begin{array}{c}890^{*} \\
(24.12)\end{array}$ & & : $2.99^{*}$ & .9943 & .4434 & $14.29^{*}$ \\
\hline & (2.33) & $\begin{array}{c}.132= \\
(3.78)\end{array}$ & $\begin{array}{r}.015^{\circ} \\
(5.66)\end{array}$ & $\begin{array}{c}-.035 \\
(3.95)\end{array}$ & & $\begin{array}{c}704 \\
(17.04)\end{array}$ & & $2.55^{\circ}$ & 9959 & .3783 & 0.50 \\
\hline \multirow[t]{2}{*}{$P$} & $\begin{array}{r}444^{\circ} \\
(2.44)^{\prime}\end{array}$ & $\begin{array}{r}.000 \\
\{004\}\end{array}$ & $\begin{array}{l}\therefore .004^{*} \\
(1.77)\end{array}$ & & & & $\begin{array}{r}.917^{*} \\
(29.87)\end{array}$ & -0.43 &.$\$ 971$ & .3621 & 0.01 \\
\hline & $\begin{array}{r}424^{*} \\
(2.31)\end{array}$ & $\begin{array}{r}.034 \\
(0.93)\end{array}$ & $\begin{array}{r}.005^{\circ} \\
(2.00)\end{array}$ & $\begin{array}{r}.009 \\
(0.95)\end{array}$ & & & $\begin{array}{r}.880^{*} \\
(17.87)\end{array}$ & 0.38 & 9971 & .3626 & 2.04 \\
\hline \multicolumn{12}{|c|}{ t/10se-IV/1979 } \\
\hline \multirow[t]{2}{*}{$\mathrm{R}$} & $\begin{array}{r}407 \\
(1.21)\end{array}$ & $\begin{array}{c}.094^{*} \\
(2.54)\end{array}$ & $\begin{array}{c}.019^{*} \\
(4.50)\end{array}$ & & $\begin{array}{r}.812^{\circ} \\
(7.58)\end{array}$ & & & $4.26^{\circ}$ & .9879 & .5242 & - \\
\hline & $\begin{array}{r}730^{\circ} \\
(2.20)^{\circ}\end{array}$ & $\begin{array}{c}.188^{*} \\
(3.98)\end{array}$ & $\begin{array}{c}-018^{*} \\
(4.79)\end{array}$ & $\begin{array}{c}.073^{*} \\
(2.89)\end{array}$ & $\begin{array}{r}.651^{*} \\
(5.72)\end{array}$ & & & $416^{*}$ & .9896 & 4853 & - \\
\hline \multirow[t]{2}{*}{$N$} & $\begin{array}{r}.051 \\
\{0.15\}\end{array}$ & $\begin{array}{r}081^{*} \\
(2.41)\end{array}$ & $\begin{array}{c}-.014^{*} \\
(3.77)\end{array}$ & & & $\begin{array}{c}.894^{*} \\
(8.74)\end{array}$ & & : $3.90^{\circ}$ & 9993 & .4813 & $5.53^{*}$ \\
\hline & $\begin{array}{r}.579 \\
(1.09)\end{array}$ & $\begin{array}{c}.158^{\prime} \\
(3.42)\end{array}$ & $\begin{array}{l}.079^{\circ} \\
(4.08)\end{array}$ & $\begin{array}{c}.05 \% \\
(2.32)\end{array}$ & & $\begin{array}{l}.149^{\circ} \\
(6.45)\end{array}$ & & $4.45^{\circ}$ & 4993 & 4591 & 120 \\
\hline \multirow[t]{3}{*}{$P$} & $\begin{array}{c}.385^{\circ} \\
(2.84)\end{array}$ & $\begin{array}{r}.020 \\
(1.10)\end{array}$ & $\begin{array}{l}\cdots .007^{*} \\
(3.25)\end{array}$ & & & & $\begin{array}{r}903^{\circ} \\
(19.11)^{\prime}\end{array}$ & 0.09 & 9996 & 2610 & 4.07 \\
\hline & $\begin{array}{l}491^{*} \\
(3.50)\end{array}$ & $\begin{array}{l}.060^{\circ} \\
(2.29)\end{array}$ & $\begin{array}{c}.007^{*} \\
(3.70)\end{array}$ & $\begin{array}{c}.028^{\circ} \\
(2.08)\end{array}$ & & & $\begin{array}{r}.84)^{*} \\
(15.45)\end{array}$ & 0.00 & .9997 & .2517 & 0.84 \\
\hline & \multicolumn{11}{|c|}{ V1074-11/1004 } \\
\hline \multirow[t]{2}{*}{$\mathbf{R}$} & $\begin{array}{r}\quad .069 \\
\quad(0.20)\end{array}$ & $\begin{array}{c}.096^{*} \\
(4.13)\end{array}$ & $\begin{array}{r}.023^{\circ} \\
(4.20)^{\circ}\end{array}$ & & $\begin{array}{c}.804^{*} \\
(16.11)\end{array}$ & & & 0.14 & .8795 & 1.0080 & - \\
\hline & $\begin{array}{r}.060 \\
(0.18)\end{array}$ & $\begin{array}{r}057 \\
(1.44)\end{array}$ & $\begin{array}{c}-024^{\circ} \\
(4.36)\end{array}$ & $\begin{array}{r}107 \\
(1.21)\end{array}$ & $\begin{array}{r}913^{*} \\
(15.92)\end{array}$ & & & -0.50 & 8809 & 1.0020 & - \\
\hline \multirow[t]{2}{*}{$N$} & $\begin{array}{r}.005 \\
(0.02)\end{array}$ & $\begin{array}{c}.051^{\circ} \\
(2.61)^{2}\end{array}$ & $\begin{array}{c}.011^{*} \\
|2.28|\end{array}$ & & & $\begin{array}{c}.941^{\circ} \\
(19.93)\end{array}$ & & -0.74 & .9985 & .8332 & 0.04 \\
\hline & $\begin{array}{r}.013 \\
\quad(0.05)\end{array}$ & $\begin{array}{c}.057^{\circ} \\
(1.71)\end{array}$ & $\begin{array}{l}.011^{\circ} \\
(2.20)\end{array}$ & $\begin{array}{l}.018 \\
(0.24)\end{array}$ & & $\begin{array}{c}.939 \\
(1930)\end{array}$ & & 0.75 & 9985 & .8437 & 0.37 \\
\hline \multirow[t]{2}{*}{$\mathrm{P}$} & $\begin{array}{r}.146 \\
(0.87)\end{array}$ & $\begin{array}{r}050^{\circ} \\
(4.29)\end{array}$ & $\begin{array}{c}.014^{\circ} \\
(4.77)\end{array}$ & & & & $\begin{array}{r}962^{\circ} \\
(33.83)\end{array}$ & $3.15^{4}$ & .9995 & .5055 & $19.61^{\circ}$ \\
\hline & $\begin{array}{r}.133 \\
(0.91)\end{array}$ & $\begin{array}{r}.001 \\
(0.08)\end{array}$ & $\begin{array}{c}.015^{\circ} \\
(5.84)^{\circ}\end{array}$ & $\begin{array}{c}139^{\circ} \\
(3.55)\end{array}$ & & & $\begin{array}{r}.988^{\circ} \\
(38.11\}\end{array}$ & 1.73 & .9996 & .4424 & $5.50^{*}$ \\
\hline
\end{tabular}

Absolute value of the t-Statistic in parernheses. Significant at 5 percent tevel. 


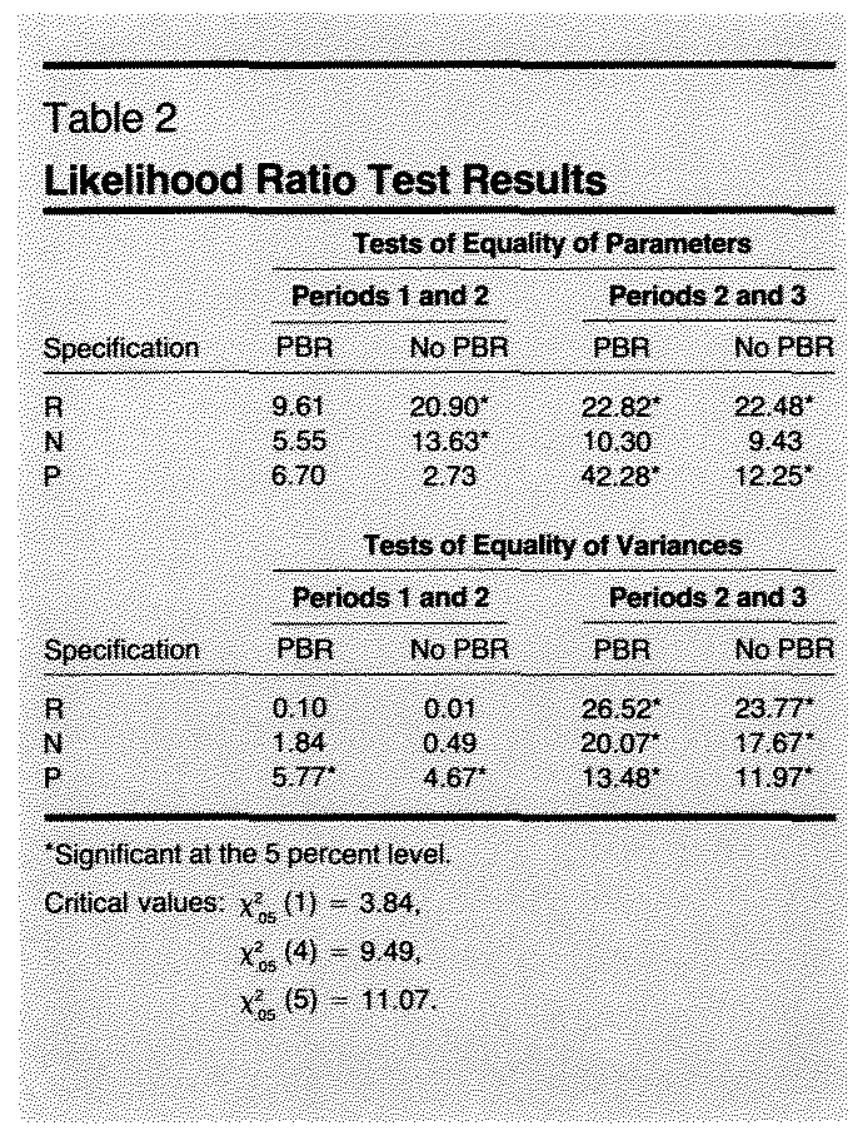

nificant in the second period, but only if the passbook rate is included, and, in the third period, only if the PBR is excluded. In this instance, the PBR enters with the wrong sign. Finally, the over-identifying restriction cannot be rejected at the 5 percent level during the first two periods in the price specification, but is rejected for the $\mathrm{I} / 1974-\mathrm{I} / 1984$ period.

It is interesting to note that, although real income is not significant in the price equation in the first period (OF in the second if the PBR is excluded), the standard error from this specification is lower than that of either the real or nominal specifications. If one thought that all these equations had the same dependent variable, one would conclude incorrectly that the price equation is the preferred specification." Moreover, the results are inconsistent with Laidler's (1983) conjecture that these equations are so similar that, if either the real or nominal specifications performs well, then so will the price specification. ${ }^{\text {t }}$

"Hence, it is not surprising that Coats and Judd and Scadding (1982a) concluded that these specifications are preferred.

${ }^{18}$ In fairness to Lajdler, he goes on to argue that none of these specifcations is likely to be stable over time, a conjecture that our empirical results support.
Furthermore, much of the apparent instability in these specifications is associated with the scale varia ble, the constant tem, the PBR and the standard error itself, rather than with the $C$ Pro or the adjustment coefficient.

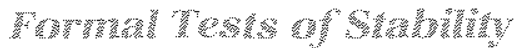

In order to test the stability of these specifications through time, likelihood ratio tests were perfomed on general specifications that allowed for differences in the variances of the equation and the coefficient of autocorrelation as well as the structural parameters." The results of tests of the equality of the coefficients and variances are presented in table 2 . The results suggest that Goldfeld's (1973) conclusion about the stablily of the real specification over the first two periods is critically dependent upon the specification of the long-run demand for money. If the PBR is included, the null hypothesis that the structural parameters are stable cannot be rejected. If it is excluded, the hypothesis is rejected. Furhermore, the hypothesis of structural stability veween the second and third periods is rejected for the real specification regardless of whether the PBR is included.

The price adjustment specification does not fare much better. While the null hypothesis of the equaliy of the structural parameters cannot be rejected for the first two periods, the insignificance of real income in either period makes the result of little interesi. Moreover, the hypothesis is rejected decisively in a comparison of the last two periods.

The results for the nominal specifcation are more encouraging. The null hypothesis is rejected during the first period only if the PBR is excluded. More importantly, the hypothesis is not rejected at the 5 per-

\footnotetext{
19 if is well known that the standard Futest for structural stabliny is sensitive to heteroscedasticity. See Toyoda (1974) and Schmidt and Sickles (1977). Thus, likelihood ratio tests were construcied to allow for heteroscedasticity. This procedure is complicated by the presenca of statistically significant serial cotrelation across some of the paritions. This was handled by obtaining maximum likelhood estimates of the coefficient of autocorrelation over each partition. The tests were conducted with the model transiomed approprately to adjust serial correlation. if there was no statisicaly significant autocorrelation in a subpenod, the untranstormed data were used, it there was prior evidence of serial correlation, the Prais-Winsien transformation was used. If there was no evidence of prior seria correlation, the initial observation was included unweighted [see Fomby, till and Johnson (1084), p. 213, and Thornion (1984) Maximum likelihood estimales of the restricted modei were obtained using an iterative procedure. The resulting likelihood rakio statistics are asymptoticaly distributed $x^{2}(J)$, where $J$ is the number of restrictions.
} 
Table 3

Estimates for the //1974-1//1984 Period With Dummy Variables for Credit Controls

\begin{tabular}{|c|c|c|c|c|c|c|}
\hline \multirow[b]{2}{*}{ Varable } & \multicolumn{6}{|c|}{ specification } \\
\hline & & & & & & \\
\hline Constant & $\begin{array}{r}141 \\
(0.52)\end{array}$ & $\begin{array}{r}155 \\
(0,54)\end{array}$ & $\begin{array}{l}102 \\
(0.46)\end{array}$ & $\begin{array}{l}099 \\
(0.45)\end{array}$ & $(0.59)$ & $\begin{array}{l}\text { (100 } \\
(0,1)\end{array}$ \\
\hline$y$ & $\begin{array}{r}047 \\
(1.50)\end{array}$ & $(500)$ & $(195)^{\circ}$ & (3) & $\begin{array}{r}0,03 \\
(0,18)\end{array}$ & $\begin{array}{r}052^{-} \\
(458)\end{array}$ \\
\hline CPR & $\begin{array}{l}023 \\
(5,16)\end{array}$ & $\begin{array}{l}022 \\
(47)\end{array}$ & $(2,40)^{\prime}$ & $(2,4)$ & (6, 015 & $(4,02)$ \\
\hline PBA & $\begin{array}{r}133 \\
(1,89)\end{array}$ & & $(0,006$ & & $(410)$ & \\
\hline $\mathrm{M}_{1}, \mathrm{P}_{4}$ & $\begin{array}{c}933 \\
(20.18)\end{array}$ & $(1971)$ & & & & \\
\hline $\mathrm{H}_{\mathrm{P}} \mathrm{P}$ & & & $(2491)^{\prime}$ & $\frac{961}{(25.64)^{\circ}}$ & & \\
\hline $\mathrm{N}_{1} \mathrm{P}_{4}$ & & & & & $\begin{array}{l}978^{\circ} \\
(4071)\end{array}$ & $(3425)$ \\
\hline Dumny 111980 & $(4.66)^{\circ}$ & $\frac{4036^{\circ}}{(4.35)}$ & $(4.27)$ & $(4.028)$ & $(2.50)$ & $\begin{array}{l}010 \\
(1911\end{array}$ \\
\hline Dumny $11 / 1980$ & 9,011 & $\left(\begin{array}{l}012 \\
(40)\end{array}\right.$ & $(2,019)$ & $(28)$ & $(1,70)$ & $(1,006)$ \\
\hline $\mathrm{SE} \times 10$ & 7935 & 8214 & 6518 & 6427 & 4057 & 4868 \\
\hline द2 & 9253 & 9200 & 9991 & 9991 & 9997 & 9995 \\
\hline h & 267 & 811 & 400 & 414 & 528 & 2713 \\
\hline Coefficent equality & 2744 & $24.59^{\prime}$ & 1019 & 930 & $48,45^{\circ}$ & 1887 \\
\hline Variance equality & 12,44 & 1173 & 704 & $5.50^{\circ}$ & $8.61 \%$ & $10,62^{\circ}$ \\
\hline
\end{tabular}

Absolute value of the $t$ statistics in parentheses, Significant at 5 percent level

cent level during the latter period, regardless of the specification. The test statistic is borderline, however, especially when the PBR is excluded. Furthermore, there is a significant increase in the variance of the specification as well as a marked change in the serial correlation of the error structure. (These results are consistent with recent findings of Lin and Oh. Thus, it appears that this specification has changed in some fundamental way during the last period.

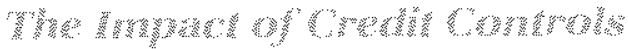

All three specifications indicate a significant increase in the variance of the equation during the latter period. Hein (1982) has presented some evidence that this change may be due in part to the credit controls of 1980; more recently, Gordon and Hafer and Thornton (1985) have shown that the credit controls had a statistically significant impact on conventional money demand equations. Hence, this marked increase in the variance of both the real and nominal specifications may be due to credit controls. Given the importance of heteroscedasticity in tests of parameter stability, it is important that this possibility be accounted for. Thus, credit control dummy variables for IL/1980 and III/1980 were included in all specifications. They were inchuded in the price specification out of curiosity, since a priori it is difficult to determine their effect on the price level.)

OLS estimates of these equations for the third period appear in table 3 . The likelihood ratio statistics for tests of the equality of the parameters and variances over the last two periods also appear. Including the credit control dummy variables substantially lowered the estimated standard errors for the real and nominal specifications, as anticipated; however, the reduction for the price specification (not surprisingly) is not as large. Both credit control dummy variables are signifcant in the nominal specification, roughty equal in 
Table 4

\section{Estimates of the Nominal Specification With $\mathrm{M} 1 \mathrm{Net}$ of $O C D$}

\begin{tabular}{|c|c|c|}
\hline & $119974-111984$ & $1 / 974-1 / 1980$ \\
\hline Constant & (.) $(0,48)$ & $\begin{array}{r}.322 \\
(0.59)\end{array}$ \\
\hline y. & $(0.27)$ & $(1,8)$ \\
\hline CPR & $\begin{array}{l}\left(.020^{\circ}\right. \\
(3,12)\end{array}$ & $\begin{array}{l}007 \% \\
(1.80)\end{array}$ \\
\hline PER & $(0.011$ & $(0.34)$ \\
\hline Mr. P & $\begin{array}{r}1.010 \\
(25.70)\end{array}$ & $\begin{array}{l}1.070 \\
(13.27)\end{array}$ \\
\hline Dummy $1 / 1980$ & $(1.65)$ & $\begin{array}{r}.029 \\
(4.94)\end{array}$ \\
\hline Duniny I1/1980 & 0.20 & $(2014)$ \\
\hline$S E \times 10^{\circ}$ & 1.1691 & 5494 \\
\hline R & 9963 & V9968 \\
\hline h? & lu 150 & 338 \\
\hline
\end{tabular}

magnitude and opposite in sign. Only the first dummy variable is significant in either the real or price specifications; its coefficient in the real money specification is approximately equal to the sum of the coefficients of the nominal money and price adjustment specifications.

Despite the obvious importance of the credit controls to these specifications, especially the nominal one, the conclusions of the stability tests are not different from those reported in table 2. Consequently, the credit controls had no effect on the outcome of tests for structural stability.

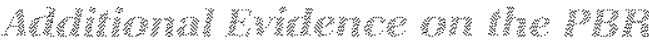

The performance of these equations is greatly affected by the presence or absence of the PBR. In particular, it bears greatly on the tests of the stability of the structural coefficients of the nominal and real specifications. The hypothesis of stability is rejected over the first two periods and is borderline over the last two periods if this variable is excluded. Furthermore, the switch of the PBR itself from statistical significance to insignificance might be considered evidence of instability. The sensitivity of these specifications to the PBR could have a sound economic basis or be a mere statistical artifact. If the latter is correct, it would appear that these specifications have been considerably less stable temporally than is generally supposed. Consequently, the role of this variable deserves additional attention.

Over most of the estimation period considered here, M1 was composed primarily of non-interest-bearing demand deposits and currency. Consequently, one could argue that the PBR constituted an important opportunity cost variable - especially over the first two periods - and that the equations are seriously misspecified if this variable is excluded. In the last period, however, the PBR might be considered a proxy for the own rate, as interest-bearing transaction accounts (paying explicit rates close to the PBR) made up a large part of $M 1 .{ }^{20}$

In order to test this explanation, M1 less other checkable deposits (OCD) was used in place of M1 in the nominal specification over the last period. This measure corresponds closely to the old currencyplus-demand-deposits definition of money, If the above conjecture is correct, this specification should perform well in the sense that both real income and the PBR should enter significantly. If the performance is poor, either there has been an underlying shift in money demand in the most recent period or money demand has never been stable.

This approach is limited by the fact that the proportion of demand deposits held by individuals declined after the nationwide introduction of NOW accounts in 1981. This could bias the results for estimates over the entire 1/1974-II/1984 period. Thus, the adjusted M1 measure was estimated for the entire third period and for the subperiod I/1974-IV/1980." The results, re" ported in table 4, show that neither the PBR nor real income enter significantly in this equation for either time period. Furthermore, the adjustment coefficient is negative, indicating an unstable dymamic specification. The results are not consistent with the conjecture that the PBR represents a critical variable in the long-run demand for money. Thus, the conclusion that none of the short-run money demand specifications have been stable is more attractive.

\footnotetext{
20The PBR might not be a good proxy for the own rate on NOW accounts over this period because it does not account for service charges associated with these deposits.

2"The real and price specifications were estimated but not reported. Asso, the equations using adjusted $M+$ were estimated over the first two periods but are not reported because they differ little from those reported in table 1.
} 


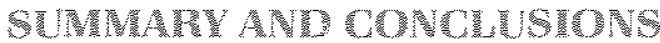

This aricle has dealt with altemative specifications of the shor-run demand for money. It has pointed out that, although three basic forms of the dynamic adjustment of money demand have been compared in the literature, they are not stricty amenable to statistical testing. The specifcations were estimated for three subperiods over the period 11/1951-11/1984. It was found that (1) allit thee specifications are very sensitive to whether the passbook savings rate is included, (2) none produce results consistent with economic theory for all three periods and (3) none exhibit temporal stabiury. White, strictly speaking, the hypothesis of temporal stability could not be rejected at the 5 percent level for Goldfeld's nominal money adjustment specification for the last two periods, it could be rejected at a slightly hoher significance levol. Furher more, the variance of this specification and the serial correlation of the error structure changed signifcantly in the last period.

Moreover, the stability test result for both the nominal and real adiusment specifications over the frst wo periods depend critically on including the passbook savings rate in the specification of long-min money demand. Subsequent investigation produced results that raise questions about the role the passbook rate has played in money demand. If the pertor mance of the passbook rate in the frst two subperiods is merely a statistical quirk, then, contrary to common belief, neither of these speciffcations is stable over these periods.

The instablity of these particular specifications is not too suprising when it is recognized that they represent reduced foms of the dynamic adjustment of money and prices, rather than structural money demand equations. Consequenty, while these specifcations are standard in the literawe, their instabily may say litte about the instability of money demand. Thus, our results cast doubt on the usefuness of these speciflcatons for shortern monetary control, without indicting money demand in general or usefuness of monetary control for shor-run economic stabilization. In ary event, the instability of these equations certainy does not preclude the usefumest of monetary growth argers in achieving longer run economic stability.

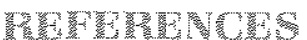

Carr, Jack, and Michael F. Daby. "The Role of Money Supply Shocks in the Short-Fun Demand For Money, "uournal of Monetary Economics (September 1981), pp. 183-99.
Chant, John F. "Dynamic Adjustments in Simple Models of the Transactions Demand for Money, "Journal of Monetary Economics (July 1976), pp. 351-66.

Chow, Gregory $C$. "On the Long-Run and Shott-Run Demand For Money," Joumal of Political Economy (April 1966), pp. 111-31.

"A Comparison of Alternative Estimators for Simultaneous Equations," Econometrica (October 1964), pp. 532-53.

Coats, Warren L., Jr. "Modeling the Short-Run Demand for Money With Exogenous Supply," Economic Inquiry (April 1982), pp. 22239 .

Feige, Edgar L. "Expectations and Adjustments in the Monetary Sector," American Economic Review (May 1967), pp. 462-73.

Fomby, Thomas B., R. Carter Hill and Stanley R. Johnson. Advanced Econometric Methods, (Springer-Verlag, 1984).

Goldfeld, Stephen M. "The Demand for Money Revisited," Brookings Papers on Economic Activity (1973:3), pp. 577-638.

"The Case of the Missing Money," Brookings Papers on Economic Activity (1976:3), pp. 683-730.

Gordon, Robert J. "The Short-Run Demand for Money: A Reconsideration, "Journal of Money, Credit and Banking, (November 1984), pp. $403-34$

Hater, R. W., and Scott E. Hein. "The Dynamics and Estimation of Short-Run Money Demand," this Review (March 1980), pp. 26-35.

"The Shitt in Money Demand: What Really Happened?" this Review (February 1982), pp. 11-16.

Mafer, R. W., and Daniel L. Thornton. "Price Expectations and the Demand for Money: A Comment," Review of Economics and Sta. vistics (forthcoming 1985).

Hein, Scott E. "Short-Run Money Growth Volatility: Evidence of Misbehaving Money Demand?" this Review (June/July 1982), pp. 27-36.

Hezzel, Robert L. "Estimating Money Demand Functions," Journal of Money, Credit and Banking (May 1984), pp. 185-93.

Hwang, Hae-shin. "Test of the Adjustment Process and Linear Homogeneity in a Stock Adjusiment Model of Money Demand," processed (1984).

Judd, John P., and John L. Scadding. "Dynamic Adjustmeni in the Demand for Money: Tests of Alternative Hypotheses," Federal Reserve Bank of San Francisco Economic Review (Fall 1982a), pp. $19-30$.

"The Search For A Stable Money Demand Function: A Survey of the Post-1973 Literature," Journal of Economic Literature (September 1982b), pp. 993-1023.

Laidler, David E. W. Monetarist Perspectives. (Harvard University Press, 1982.)

"The 1981-82 Velocity Decline: A Structural Shift in income or Money Demand?" Monetary Targeting and Velocity, Proceedings of a Conference held at the Federal Reserve Bank of San Francisco (December 1983), pp. 100-03.

"The Demand for Money in the United States - Yet Again," in Karl Brunner and Allan M. Meltzer, eds., On the State of Macro-economics, Carnegie-Rochester Conference Series on Public Policy (North-Holland, Spring 1980), pp. 219-71.

Lin, Kuan-Pin and John S. On. "Stability of the U.S. Short-Run Money Demand Function, 1959-81," Journal of Finance (December 1984), pp. 1383-96.

Milboume, Ross D. "Price Expectations and the Demand for Money: Resolution of a Paradox," Review of Economics and Statistics (November 1983), pp. \$287-305. 
Mottey, Brian. "Dynamic Adjustment in Money Demand," Federa! Reserve Bank of San Francisco Economic Review (Winter 1984), pp. 22-26.

"The Demand-for-Money Function for the Household Sector - Some Preliminary Findings," Journal of Finance (September 1967), pp. 405-18.

Schmidt, Peter, and Robin Sickles. "Some Further Evidence on the Use of the Chow Test Under Heteroscedasticity," Econometrica (July 1977), pp. 1293-98.
Thornton, Daniel L. "On the Treatment of the Initial Observation in the AR(1) Regression Model," Federal Reserve Bank of St. Louis Working Paper No. 84-003 (1984).

Toyoda, Toshihisa. "Use of the Chow Test Under Heteroscedasticity," Econometrica (May 1974), pp. 601-08.

Walters, A. A. "The Demand For Money - The Dynamic Properties of the Multiplier," Joumal of Political Economy (June 1967), po. $293-98$.

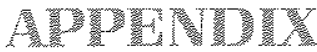

The purpose of this appendix is to show that equations 7,8 and 9 minimize the residual sum of squares in different directions and, because of this, the residuals from these specifications are not statistically comparable. This appendix draws heavily on the work of Chow (1964). Consider the standard regression model

$$
\mathrm{Y}=\mathrm{X} \beta+\mathrm{u}
$$

where $Y$ is a $T$ by 1 vector of the dependent variable, $X$ is a $T$ by $k$ matrix of independent variables, $\beta$ is a $k$ by 1 vector of unknown parameters and $u$ is a $T$ by 1 vector of random errors. It is now commonly understood that the least squares estimate of the vector $\beta$ is geometrically the particular linear combination of the regressor variables that minimizes the squared distance between the vector $Y$ and the space spanned by the columns of $X$. It is less well known that this estimate is obtained by imposing a particular direction and scale normalization rule. To see this, consider the more general model

$$
\beta_{1} Y_{2}+\beta_{2} Y_{3}=\mu_{1} X_{2}+\mu_{3} X_{4}+\mathbf{u}_{r}
$$

where $Y_{1}, Y_{3}, X_{1}$ and $X_{2}$ are $T$ by 1 vectors with scalar parameters $\beta_{1}, \beta_{2}, \mu_{1}$ and $\mu_{2}$. Chow notes that estimates of the parameters of this model could be obtained by least squares by projecting the linear combination of the $Y$ 's (that is, $\beta_{1} Y_{1}+\beta_{2} Y_{3}$ ) on the space spanned by $X_{1}$ and $X_{2}$. In this case, least squares estimates would be obtained by projecting the vector $\beta_{1} Y_{1}+\beta_{2} Y_{2}$ in the direction of $\left(X_{1} X_{2}\right)$. This would establish the directionnormalization. Once this is accomplished, the scale can be obtained by choosing any scale-normalization (for example, $\beta_{1}, \beta_{2}, \mu_{1}$ or $\mu_{2}=1$ ). In this case, directionnormalization and scale-normalization are separate. Chow points out, however, that if the restriction $\beta_{1}=1$ were imposed before the minimization, the vector $Y_{1}$ alone is projected on the space spanned by $\left(X_{z} X_{k} X_{z}\right)$. That is, the analyst is asserting that the vector $Y_{v}$, has a mean vector in the space $\left(Y_{2} X_{1} X_{2}\right)$ and an additive random error orthogonal to the space spanned by $\left(X_{2}\right.$ $\mathrm{X}_{1}, \mathrm{X}_{2}$ ). Alternatively, if the restriction $\beta_{2}=1$ were imposed, the least squares estimates would be obtained by projecting the vector $Y_{2}$ on the space spanned by $Y_{1}$ $X_{1} X_{2}$. This would imply that the analyst viewed $Y_{2}$ as having a mean vector in the space $\left(Y_{1} X_{1} X_{n}\right)$ and an additive random error vector orthogonal to $\left(Y_{1}, X_{1}, X_{z}\right)$.

Clearly, the residual vectors obtained from these different orthogonal projections are in general different random variables and are, therefore, not comparable. The same is true of error vectors from equations 7 , 8 and 9 . We can establish this by noting that minimization is obtained after imposing different restrictions (normalization rules). For example, the implicit coefficient on $(M-P)_{1}$ is set equal to one in equation 7 . Likewise, the coefficients on $M_{t}$ and $P_{1}$, respectively, are set equal to one in equations 8 and 9 . 